\title{
Evaluation of radioinduced damage and repair capacity in blood lymphocytes of breast cancer patients
}

P.A. Nascimento, M.A. da Silva, E.M. Oliveira,

M.F. Suzuki and K. O kazaki

\author{
Supervisão de Radiobiologia, Departamento de Bioengenharia, \\ Instituto de Pesquisas Energéticas e N ucleares, CNEN/SP, \\ São Paulo, SP, Brasil
}

\begin{abstract}
Correspondence

K. O kazaki

Travessa R, 400

05508-900 São Paulo, SP

Brasil

Fax: +55-11-3816-9232

E-mail: kokazaki@ net.ipen.br

Research supported by CN Pq. Publication supported by FAPESP.

Received June 12, 2000 Accepted November 29, 2000

Genetic damage caused by ionizing radiation and repair capacity of blood lymphocytes from 3 breast cancer patients and 3 healthy donors were investigated using the comet assay. The comets were analyzed by two parameters: comet tail length and visual classification. Blood samples from the donors were irradiated in vitro with a ${ }^{60} \mathrm{Co}$ source at a dose rate of $0.722 \mathrm{~Gy} / \mathrm{min}$, with a dose range of 0.2 to $4.0 \mathrm{~Gy}$ and analyzed immediately after the procedure and 3 and $24 \mathrm{~h}$ later. The basal level of damage and the radioinduced damage were higher in lymphocytes from breast cancer patients than in lymphocytes from healthy donors. The radioinduced damage showed that the two groups had a similar response when analyzed immediately after the irradiations. Therefore, while the healthy donors presented a considerable reduction of damage after $3 \mathrm{~h}$, the patients had a higher residual damage even $24 \mathrm{~h}$ after exposure. The repair capacity of blood lymphocytes from the patients was slower than that of lymphocytes from healthy donors. The possible influence of age, disease stage and mutations in the BRCA1 and BRCA2 genes are discussed. Both parameters adopted proved to be sensitive and reproducible: the doseresponse curves for DNA migration can be used not only for the analysis of cellular response but also for monitoring therapeutic interventions. Lymphocytes from the breast cancer patients presented an initial radiosensitivity similar to that of healthy subjects but a deficient repair mechanism made them more vulnerable to the genotoxic action of ionizing radiation. However, since lymphocytes from only 3 patients and 3 normal subjects were analyzed in the present paper, additional donors will be necessary for a more accurate evaluation.
\end{abstract}

Key words

- Comet assay

- DNA damage

- DNA repair

- Ionizing radiation

- Breast cancer

- Blood lymphocytes

\section{Introduction}

Breast cancer has attracted increasing attention over the last years because of its high incidence among women. In industrialized countries one in ten women develops this type of cancer some time during her life (1).

The etiology of breast cancer is multifactorial, including various risk factors such as environmental, hormonal and hereditary ones. Most cases (about 80\%) are considered sporadic, being caused by somatic events and 
about $20 \%$ have a family history including a $5 \%$ rate of autosomal dominant mutations of high penetrance (2).

Alterations of the tumor suppressor genes BRCA1 and BRCA2 confer a high risk of breast cancer. Mutations in the BRCA1 gene are involved in about $50 \%$ of families with a high incidence of breast cancer and in at least $80 \%$ of families with a high rate of early breast and ovarian cancers (3). Similarly, mutations of the BRCA2 gene cause early breast cancer in women and also a higher risk in men (4).

Although breast and ovarian cancers are types of neoplastic disease with a strong familial component, many uncertainties exist about the role of hereditary predisposition because of many factors that impair analysis. These include the existence of sporadic cancer and mutations of variable penetrance, in addition to the heterogeneity of the disease as revealed by epidemiological evidence and molecular analysis (1).

The deficiency in repair has been pointed out as a factor of susceptibility to cancer development. The biological importance of the DNA repair mechanism in cancer development is illustrated by recessive autosomal disease such as chromosome fragility syndrome. Affected individuals, i.e., subjects with xeroderma pigmentosum, Fanconi's anemia, or ataxia telangiectasia, are deficient in a type of repair and are at high risk for malignancy when exposed to specific mutagens such as UV light, alkylating agents and ionizing radiation (5). There are many cell repair mechanisms and, depending on the type of DNA lesion, a specific repair mechanism is initiated. Recent molecular studies have shown that the BRCA1 and BRCA2 genes are involved in DNA repair. Both protein products act directly or indirectly with yeast Rad51 protein homologues or Escherichia coli RecA protein which participates in DNA double-strand break or recombinant repair $(2,6)$.

In addition to these genes, other tumor suppressors such as the p53 and AT genes, which are involved in breast cancer, participate in cell repair processes $(7,8)$. On this basis, the analysis of the association between cell repair capacity and genotoxic exposure to environmental agents in breast cancer patients would be of great interest.

There are few studies on this subject and some data reported in the literature are contradictory. Some investigators found a high sensitivity and a reduced repair capacity in peripheral blood lymphocytes from breast cancer patients when exposed to X-rays, gamma and UV light, as evaluated by the determination of chromosome aberrations (9-11) and by the micronucleus test (12). While Hsu et al. (13), using bleomycin in a mutagenic test, did not find a significant difference between blood cells from breast cancer patients and healthy subjects in terms of number of chromatid breaks per cell, Jaloszynski et al. (14) reported a high sensitivity and reduced repair capacity in peripheral blood cells from breast cancer patients using the comet assay. Rothfuss et al. (15) reported a higher sensitivity to gamma radiation and oxygen peroxide in patients with BRCA1 mutation than in healthy subjects using the micronucleus assay but not when using the comet assay.

In the present study, we investigated the damage induced by ${ }^{60} \mathrm{Co}$ gamma radiation and the repair capacity of 3 breast cancer patients ( 2 with cancer cases in their families) by analyzing peripheral blood lymphocytes immediately and 3 and $24 \mathrm{~h}$ after irradiation by the comet assay. The objective was to determine if the irradiated cells of these patients present the same radiosensitivity and repair the damage with the same intensity as observed in healthy individuals.

\section{Material and Methods}

\section{Donors}

Blood samples from 3 healthy subjects 
and from 3 patients with breast cancer were obtained for analysis from Instituto de Radioterapia de São Paulo (São Paulo, SP, Brazil), by written authorization. This project was evaluated and approved by the Ethics Committee on Research of IPEN-CNEN/SP (No. 006/CEP).

Healthy donors. The group of healthy donors consisted of 2 women (donor A, 49 years and donor B, 40 years) and 1 man (donor C, 45 years), all of them nonsmokers who were not consuming alcohol or taking any medication at the time of blood collection. None of them had cases of cancer in the family.

Breast cancer patients. This group consisted of 3 women with ductal breast carcinoma (donor D, 47 years; E, 72 years; F, 65 years) in the primary stage and with no metastasis. All patients had been mastectomized but none had been submitted to chemotherapy or radiotherapy at the time of blood sampling. Donor D had an uncle with intestinal cancer, an aunt with breast cancer and a brother with skin cancer. Donor F had a brother with prostate cancer and a daughter with ovarian cancer. Donor E had no cancer case in her family.

All donors completed a written questionnaire to obtain information related to their life style, such as dietary habits, medical history and exposure to chemical and physical agents.

\section{Blood sample collection and irradiation}

About $5 \mathrm{ml}$ of blood was collected from each donor by venipuncture into heparinized tubes. The samples were then fractionated in Eppendorf tubes in equal volumes of $0.8 \mathrm{ml}$ each and irradiated with a panoramic ${ }^{60} \mathrm{Co}$ source at 0.2, 0.6, 1.0, 2.0 and 4.0 Gy (dose rate of $0.722 \mathrm{~Gy} / \mathrm{min}$ ) at room temperature. One tube was maintained as control (0 Gy).

\section{Comet assay}

The alkaline version described by Singh et al. (16) was used, with some modifications. After irradiation, all samples were kept on ice to avoid repair of radioinduced damage (no incubation period) for the evaluation of initial damage.

For repair evaluation, blood samples were incubated at $37^{\circ} \mathrm{C}$ for 3 and $24 \mathrm{~h}$ after irradiation. These periods were chosen based on literature data about the repair kinetics of induced damage evaluated over periods ranging from minutes to some hours after exposure to low linear energy transfer (LET) radiation (16-18). The period of $24 \mathrm{~h}$ was adopted because it was considered sufficient to analyze non-repaired damage.

For each fractionated blood sample, irradiated or not, fully frosted microscope slides (in duplicate) were covered with $300 \mu \mathrm{l}$ of normal melting agarose (Sigma Chemical Co., St. Louis, MO, USA; $0.75 \% \mathrm{Ca}^{2+}$ and $\mathrm{Mg}^{2+}$ free PBS at $65^{\circ} \mathrm{C}$ ) and maintained at $4^{\circ} \mathrm{C}$ for 5-10 min for gel solidification. On this gel layer, $5 \mu$ l of blood was dissolved in $90 \mu 1$ of low melting agarose (Sigma; $0.5 \%$ $\mathrm{Ca}^{2+}$ and $\mathrm{Mg}^{2+}$ free PBS at $37^{\circ} \mathrm{C}$ ). After solidification at $4^{\circ} \mathrm{C}$, another $90-\mu 1$ layer of low melting agarose was laid.

The slides were then placed vertically in a cuvette containing lysis solution $(2.5 \mathrm{M}$ $\mathrm{NaCl}, 100 \mathrm{mM}$ EDTA, $10 \mathrm{mM}$ Tris, $1 \%$ sodium sarcosinate, $1 \%$ Triton X-100, and $10 \% \mathrm{DMSO}$ ) for $2 \mathrm{~h}$ at $4^{\circ} \mathrm{C}$ to remove proteins. After lysis, the slides were placed sideby-side in a horizontal electrophoresis tank (10 x $20 \mathrm{~cm}$, Permatron) and immersed in alkaline buffer, $\mathrm{pH}>12$ ( $1 \mathrm{mM}$ EDTA and $300 \mathrm{mM} \mathrm{NaOH}$ ) for $30 \mathrm{~min}$ to allow DNA damage expression, and electrophoresis was performed at $25 \mathrm{~V}, 300 \mathrm{~mA}$ (Pharmacia, Uppsala, Sweden) for $30 \mathrm{~min}$ at $4^{\circ} \mathrm{C}$.

The slides were then neutralized three times with $0.4 \mathrm{M}$ Tris buffer, $\mathrm{pH} 7.5$, for 5 min each time and stained with $50 \mu 1$ ethidium bromide ( $20 \mu \mathrm{g} / \mathrm{ml}$; Sigma), covered with coverslips and maintained in a humid chamber protected from light. All steps after lysis were conducted with no light to avoid 
additional damage to the DNA.

\section{Microscope slide analysis}

The slides were analyzed with a fluorescent microscope (Carl Zeiss) at 200X, with a $515-560-\mathrm{nm}$ exciting filter and a $590-\mathrm{nm}$ barrier filter. Approximately 50-70 comets were analyzed for each radiation dose. All comets were photographed using black and white ASA 400 TMAX Kodak film.

\section{Damage and repair evaluation}

The radioinduced damage was evaluated in two ways:

Comet measurement. The analysis was done on the negative by projecting the comet image as a photo slide (Zoom Cabin). DNA damage was quantified for each cell by measuring the total length (head and tail) according to the criteria adopted by McKelveyMartin et al. (19).

Damage category. Damage was assigned to 5 classes (0-4) based on the visual aspect of the comets, considering the extent of DNA migration according to the criteria established by Visvardis et al. (20). Comets with a bright head and no tail were classified as class 0 (cells with no DNA migration) and comets with a small head and a long diffuse tail were classified as class 4 (severely damaged cells). Comets with intermediate characteristics were assigned to classes 1,2 and 3.

Radioinduced DNA damage (DD) and repair capacity $(\mathrm{R})$ were estimated quantitatively 3 and $24 \mathrm{~h}$ after irradiation using the equations described by Jaloszynski et al. (14). DD values ranged from 0 to 400 arbitrary units (au), corresponding to situations ranging from no damaged comets to all comets extremely damaged.

$$
\mathrm{DD}=\left(\mathrm{n}_{1}+2 \mathrm{n}_{2}+3 \mathrm{n}_{3}+4 \mathrm{n}_{4}\right) /(\Sigma / 100)
$$

$\mathrm{R}=(\mathrm{DD}$ immediately after exposure - DD after exposure at time 3 or $24 \mathrm{~h}) /(\mathrm{DD}$ imme- diately after exposure - $\left.\mathrm{DD}_{0}\right) 100 \%$, where, DD: DNA damage (au), $\mathrm{n}_{1}-\mathrm{n}_{4}$ : number of class 1 to 4 comets, $\Sigma$ : total number of scored comets, including class 0 , and $\mathrm{DD}_{0}$ : DNA damage in nonirradiated samples.

\section{Statistical analysis}

The radioinduced damage and repair capacity 3 and $24 \mathrm{~h}$ after irradiation were compared between groups by nonparametric twoway ANOVA. Dose-response curves were fitted according to nonlinear regression:

$$
\mathrm{Y}=\mathrm{A} \cdot \mathrm{e}^{(-\mathrm{kD})}+\mathrm{B}
$$

where, Y: tail length $(\mu \mathrm{m})$ or DNA damage (au); A, B, k: constants; D: radiation dose (Gy).

The statistical analyses were performed using the Graph Pad Prism Software.

\section{Results}

In this study, radioinduced damage and DNA repair capacity of blood lymphocytes from breast cancer patients and healthy subjects were compared by the comet assay 3 and $24 \mathrm{~h}$ after ${ }^{60} \mathrm{Co}$ irradiation. Nonirradiated cells showed a nuclear matrix with a fluorescent halo formed by DNA filaments limited to the original nuclear area (nucleoid or nucleus-like structure) (19). The nucleoid diameter was about $28-29.5 \mu \mathrm{m}$. The irradiated cells formed images similar to comets with a head and tail, and tail length increased with radiation dose.

\section{Evaluation of nonirradiated cells}

Comets of nonirradiated cells from both groups were analyzed by measuring tail length and DNA damage 3 and $24 \mathrm{~h}$ after irradiation (Table 1).

No significant differences in basal values were detected between groups by visual classification $(\mathrm{P}>0.05)$ although a slight ten- 
dency to an increase was observed in the cancer group. In contrast, significant differences were detected by tail length measurement $(\mathrm{P}<0.05)$.

No significant difference was observed in either parameter with respect to time of incubation $(\mathrm{P}>0.05)$.

\section{Evaluation of radioinduced damage}

The results for blood cells irradiated with ${ }^{60} \mathrm{Co}$ gamma radiation from healthy donors $(\mathrm{A}, \mathrm{B}, \mathrm{C})$ and from breast cancer patients (D, E, F) analyzed at different times after irradiation are presented in Tables 2 and 3.

In both groups, total length and tail length increased with dose, but the values were smaller at $24 \mathrm{~h}$, and head diameter tended to decrease with dose.

As expected, the percentage of affected cells (comets with tails) increased with dose in both groups. Three hours later the frequency of affected cells was higher in pa- tients at all radiation doses.

The quantitative estimation of radioinduced DNA damage based on visual classification is presented in Table 4. In both groups the DD values increased as a function of dose, with a tendency to decrease with time.

Figure 1 shows the dose-response curve for DNA migration (tail length and DNA damage) fitted by nonlinear regression. There

Table 1 - Basal values obtained by the comet assay for blood samples from 3 healthy donors and 3 breast cancer patients.

Data are reported as means \pm SEM .

\begin{tabular}{lccc}
\hline Group & Time after irradiation & Tail length $(\mu \mathrm{m})$ & DNA damage $(\mathrm{au})$ \\
\hline Healthy & $0 \mathrm{~h}$ & $1.14 \pm 0.11$ & $13.33 \pm 1.76$ \\
& $3 \mathrm{~h}$ & $1.32 \pm 0.52$ & $10.00 \pm 9.26$ \\
Patient & $24 \mathrm{~h}$ & $1.21 \pm 0.57$ & $12.89 \pm 2.56$ \\
& $0 \mathrm{~h}$ & $2.07 \pm 0.19$ & $15.85 \pm 1.89$ \\
& $3 \mathrm{~h}$ & $2.39 \pm 1.38$ & $14.03 \pm 1.46$ \\
& $24 \mathrm{~h}$ & $4.00 \pm 0.66$ & $14.93 \pm 4.47$
\end{tabular}

Table 2 - Mean values of comet length (head and tail) obtained for blood samples from 3 healthy donors, processed immediately or 3 and $24 \mathrm{~h}$ after in vitro exposure to ${ }^{60} \mathrm{Co}$.

Tail length $=$ Total length - head length

\begin{tabular}{|c|c|c|c|c|c|c|c|}
\hline $\begin{array}{l}\text { Time after } \\
\text { irradiation }\end{array}$ & $\begin{array}{l}\text { Dose } \\
\text { (Gy) }\end{array}$ & $\begin{array}{l}\text { Number of } \\
\text { cells }\end{array}$ & $\begin{array}{l}\text { Total length } \\
(\mu \mathrm{m})\end{array}$ & $\begin{array}{l}\text { Head length } \\
\qquad(\mu \mathrm{m})\end{array}$ & $\begin{array}{l}\text { Tail length } \pm \text { SEM } \\
(\mu \mathrm{m})\end{array}$ & $\begin{array}{l}\text { Number of cells } \\
\text { without a tail (\%) }\end{array}$ & $\begin{array}{l}\text { Number of cells } \\
\text { with a tail (\%) }\end{array}$ \\
\hline \multirow[t]{6}{*}{$\mathrm{Oh}$} & 0.0 & 168 & 30.16 & 29.02 & $1.14 \pm 0.11$ & 151 (89.9) & $17(10.1)$ \\
\hline & 0.2 & 187 & 46.14 & 28.67 & $17.47 \pm 3.80$ & $53(28.3)$ & $134(71.7)$ \\
\hline & 0.6 & 163 & 54.84 & 28.10 & $26.74 \pm 8.60$ & 34 (20.9) & 129 (79.1) \\
\hline & 1.0 & 155 & 65.54 & 29.16 & $36.38 \pm 5.83$ & $22(14.2)$ & 133 (85.8) \\
\hline & 2.0 & 163 & 72.10 & 28.74 & $43.36 \pm 4.27$ & $4(2.5)$ & 159 (97.5) \\
\hline & 4.0 & 177 & 104.40 & 27.75 & $76.65 \pm 11.21$ & $0(0.0)$ & 177 (100.0) \\
\hline \multirow[t]{6}{*}{$3 \mathrm{~h}$} & 0.0 & 171 & 31.49 & 30.17 & $1.32 \pm 0.52$ & 160 (93.6) & $11(6.4)$ \\
\hline & 0.2 & 202 & 32.34 & 29.58 & $2.76 \pm 0.63$ & $171(84.7)$ & 31 (15.3) \\
\hline & 0.6 & 193 & 35.46 & 30.34 & $5.12 \pm 0.93$ & $143(74.1)$ & $50(25.9)$ \\
\hline & 1.0 & 180 & 35.19 & 30.04 & $5.15 \pm 0.63$ & 124 (68.9) & $56(31.1)$ \\
\hline & 2.0 & 211 & 41.23 & 29.43 & $11.80 \pm 1.85$ & 113 (53.6) & $98(46.4)$ \\
\hline & 4.0 & 223 & 44.46 & 28.04 & $16.42 \pm 2.05$ & 92 (41.3) & 131 (58.7) \\
\hline \multirow[t]{6}{*}{$24 \mathrm{~h}$} & 0.0 & 163 & 30.60 & 29.39 & $1.21 \pm 0.57$ & 152 (93.3) & $11(6.7)$ \\
\hline & 0.2 & 195 & 33.33 & 28.60 & $4.73 \pm 2.02$ & 149 (76.4) & $46(23.6)$ \\
\hline & 0.6 & 170 & 36.69 & 27.44 & $9.25 \pm 1.71$ & 110 (64.7) & $60(35.3)$ \\
\hline & 1.0 & 152 & 35.03 & 27.18 & $7.85 \pm 1.74$ & $94(61.8)$ & $58(38.2)$ \\
\hline & 2.0 & 198 & 40.97 & 27.09 & $13.88 \pm 0.56$ & 106 (53.5) & 92 (46.5) \\
\hline & 4.0 & 208 & 47.07 & 26.16 & $20.91 \pm 1.59$ & 85 (40.9) & 123 (59.1) \\
\hline
\end{tabular}


Table 3 - Mean values of comet length (head and tail) obtained for blood samples from 3 breast cancer patients, processed immediately or 3 and $24 \mathrm{~h}$ after in vitro exposure to ${ }^{60} \mathrm{Co}$.

Tail length $=$ Total length - head length .

\begin{tabular}{|c|c|c|c|c|c|c|c|}
\hline $\begin{array}{l}\text { Time after } \\
\text { irradiation }\end{array}$ & $\begin{array}{l}\text { Dose } \\
\text { (Gy) }\end{array}$ & $\begin{array}{l}\text { Number of } \\
\text { cells }\end{array}$ & $\begin{array}{l}\text { Total length } \\
\quad(\mu \mathrm{m})\end{array}$ & $\begin{array}{l}\text { Head length } \\
(\mu \mathrm{m})\end{array}$ & $\begin{array}{c}\text { Tail length } \pm \text { SEM } \\
(\mu \mathrm{m})\end{array}$ & $\begin{array}{l}\text { Number of cells } \\
\text { without a tail (\%) }\end{array}$ & $\begin{array}{c}\text { Number of cells } \\
\text { with a tail (\%) }\end{array}$ \\
\hline \multirow[t]{6}{*}{$\mathrm{Oh}$} & 0.0 & 198 & 29.98 & 27.91 & $2.07 \pm 0.19$ & 182 (91.9) & $16(8.1)$ \\
\hline & 0.2 & 169 & 34.72 & 27.47 & $7.25 \pm 1.48$ & $111(65.7)$ & $58(34.3)$ \\
\hline & 0.6 & 191 & 46.31 & 26.88 & $19.43 \pm 2.20$ & $62(32.5)$ & $129(67.5)$ \\
\hline & 1.0 & 180 & 58.07 & 25.77 & $32.30 \pm 1.62$ & $10(5.6)$ & $170(94.4)$ \\
\hline & 2.0 & 186 & 71.60 & 25.97 & $45.63 \pm 2.00$ & $1(0.5)$ & 185 (99.5) \\
\hline & 4.0 & 167 & 91.79 & 25.18 & $66.61 \pm 3.47$ & $0(0.0)$ & $167(100.0)$ \\
\hline \multirow[t]{6}{*}{$3 \mathrm{~h}$} & 0.0 & 206 & 30.28 & 27.89 & $2.39 \pm 1.38$ & $193(93.7)$ & $13(6.3)$ \\
\hline & 0.2 & 197 & 36.32 & 27.55 & $8.77 \pm 1.73$ & $129(65.5)$ & 68 (34.5) \\
\hline & 0.6 & 161 & 43.50 & 26.55 & $16.95 \pm 2.92$ & 78 (48.4) & 83 (51.6) \\
\hline & 1.0 & 170 & 45.36 & 26.45 & $18.91 \pm 3.13$ & $92(54.1)$ & 78 (45.9) \\
\hline & 2.0 & 219 & 49.71 & 26.70 & $23.01 \pm 2.45$ & $86(39.3)$ & $133(60.7)$ \\
\hline & 4.0 & 171 & 67.28 & 26.03 & $41.25 \pm 8.39$ & $36(21.1)$ & 135 (78.9) \\
\hline \multirow[t]{6}{*}{$24 \mathrm{~h}$} & 0.0 & 183 & 32.10 & 28.10 & $4.00 \pm 0.66$ & $158(86.3)$ & 25 (13.7) \\
\hline & 0.2 & 179 & 33.37 & 27.79 & $5.58 \pm 1.18$ & 141 (78.8) & 38 (21.2) \\
\hline & 0.6 & 163 & 37.02 & 27.01 & $10.01 \pm 1.89$ & $118(72.4)$ & 45 (27.6) \\
\hline & 1.0 & 186 & 42.03 & 26.94 & $15.09 \pm 5.67$ & $115(61.8)$ & 71 (38.2) \\
\hline & 2.0 & 186 & 45.46 & 26.40 & $19.06 \pm 4.32$ & 91 (48.9) & 95 (51.1) \\
\hline & 4.0 & 185 & 52.72 & 26.30 & $26.42 \pm 5.12$ & 72 (38.9) & $113(61.1)$ \\
\hline
\end{tabular}

Table 4 - Mean values of DNA damage obtained for blood samples from 3 healthy donors and 3 breast cancer patients, processed immediately or 3 and $24 \mathrm{~h}$ after in vitro exposure to ${ }^{60} \mathrm{Co}$.

\begin{tabular}{|c|c|c|c|c|c|c|c|}
\hline \multicolumn{4}{|c|}{ Healthy } & \multicolumn{4}{|c|}{ Patient } \\
\hline Time after irradiation & Dose (Gy) & Number of cells & DNA damage (au) & Time after irradiation & Dose (Gy) & Number of cells & DNA damage (au) \\
\hline \multirow[t]{6}{*}{$\mathrm{Oh}$} & 0.0 & 150 & $13.33 \pm 3.06$ & $\mathrm{Oh}$ & 0.0 & 177 & $15.85 \pm 3.27$ \\
\hline & 0.2 & 154 & $103.38 \pm 16.30$ & & 0.2 & 163 & $62.36 \pm 11.12$ \\
\hline & 0.6 & 153 & $164.09 \pm 29.21$ & & 0.6 & 152 & $125.31 \pm 25.20$ \\
\hline & 1.0 & 154 & $207.90 \pm 37.54$ & & 1.0 & 152 & $158.05 \pm 53.84$ \\
\hline & 2.0 & 154 & $232.46 \pm 11.55$ & & 2.0 & 152 & $232.18 \pm 16.44$ \\
\hline & 4.0 & 151 & $290.59 \pm 18.34$ & & 4.0 & 152 & $290.82 \pm 20.10$ \\
\hline \multirow[t]{6}{*}{$3 \mathrm{~h}$} & 0.0 & 150 & $10.00 \pm 3.46$ & $3 \mathrm{~h}$ & 0.0 & 194 & $14.03 \pm 2.54$ \\
\hline & 0.2 & 150 & $31.33 \pm 16.04$ & & 0.2 & 160 & $62.15 \pm 11.36$ \\
\hline & 0.6 & 152 & $57.00 \pm 16.64$ & & 0.6 & 139 & $89.06 \pm 16.08$ \\
\hline & 1.0 & 152 & $55.36 \pm 14.45$ & & 1.0 & 149 & $84.82 \pm 19.44$ \\
\hline & 2.0 & 150 & $82.67 \pm 11.72$ & & 2.0 & 160 & $162.17 \pm 55.34$ \\
\hline & 4.0 & 154 & $123.97 \pm 11.12$ & & 4.0 & 152 & $230.28 \pm 78.26$ \\
\hline \multirow[t]{6}{*}{$24 \mathrm{~h}$} & 0.0 & 148 & $12.89 \pm 4.44$ & $24 \mathrm{~h}$ & 0.0 & 179 & $14.93 \pm 7.74$ \\
\hline & 0.2 & 150 & $31.33 \pm 16.29$ & & 0.2 & 164 & $33.71 \pm 6.83$ \\
\hline & 0.6 & 152 & $48.17 \pm 19.80$ & & 0.6 & 157 & $53.53 \pm 28.15$ \\
\hline & 1.0 & 155 & $49.44 \pm 21.10$ & & 1.0 & 149 & $76.57 \pm 9.93$ \\
\hline & 2.0 & 154 & $81.72 \pm 40.10$ & & 2.0 & 181 & $110.97 \pm 9.33$ \\
\hline & 4.0 & 150 & $125.33 \pm 29.14$ & & 4.0 & 150 & $197.33 \pm 86.01$ \\
\hline
\end{tabular}


was a significant increase in DNA migration as a function of dose at all 3 periods of time analyzed.

Both groups showed a similar response when analyzed immediately after exposure. Analysis of variance showed that there were no differences in comet length between groups $(\mathrm{P}>0.05)$, but visual classification showed a significant difference $(\mathrm{P}<0.05)$.

Both tail length and DD values showed a considerable reduction after 3 and $24 \mathrm{~h}$ when compared with the values obtained immediately after exposure, with significant differences between groups after $3 \mathrm{~h}(\mathrm{P}<0.01)$ and $24 \mathrm{~h}(\mathrm{P}<0.05)$. The breast cancer group presented a greater quantity of damage than controls.

\section{Evaluation of cell repair}

Repair capacity of radioinduced damage in blood cells was estimated by the formula described by Jaloszynski et al. (14). The individual values and means at 3 and $24 \mathrm{~h}$ are illustrated in Figure 2.

There were interindividual differences in repair capacity of blood lymphocytes in both groups, but this variability was more marked among patients.

Figure 2 shows that radioinduced damage was less efficiently repaired among patients than among controls after all doses at both times of analysis. Among patients, the blood cells of donor E showed a better effi-
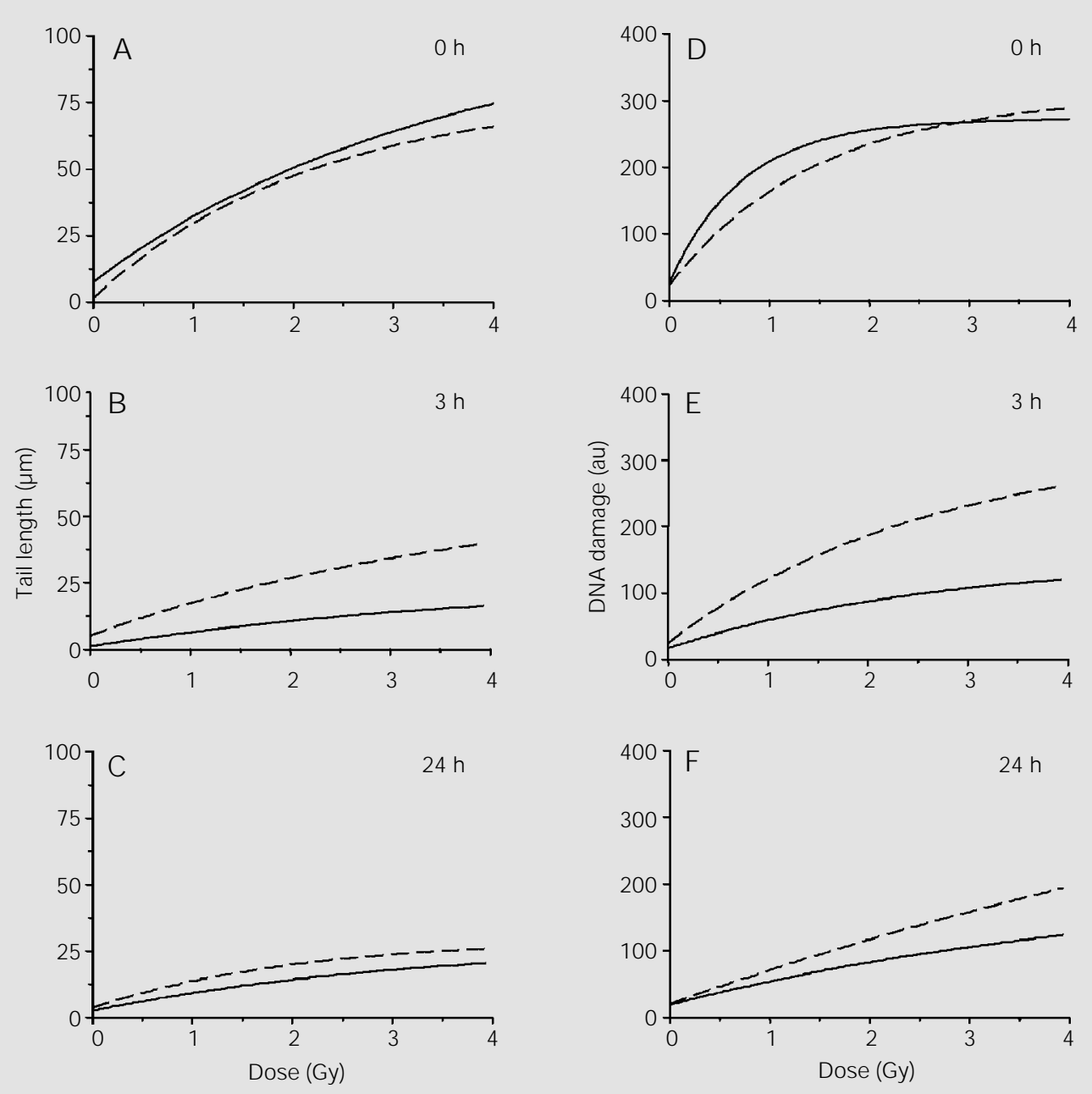

Figure 1 - Dose-response curves of DNA migration obtained for blood samples from 3 healthy donors (full lines) and 3 breast cancer patients (broken lines), processed immediately $(A, D)$ or $3(\mathrm{~B}, \mathrm{E})$ and $24 \mathrm{~h}(\mathrm{C}, \mathrm{F})$ after in vitro exposure to ${ }^{60} \mathrm{Co}$. 
Figure 2 - Repair capacity observed in blood samples from 3 healthy donors $(A, B), 3$ breast cancer patients (C, D) and group means ( $E, F), 3$ and $24 \mathrm{~h}$ after in vitro exposure to ${ }^{60} \mathrm{Co}$.
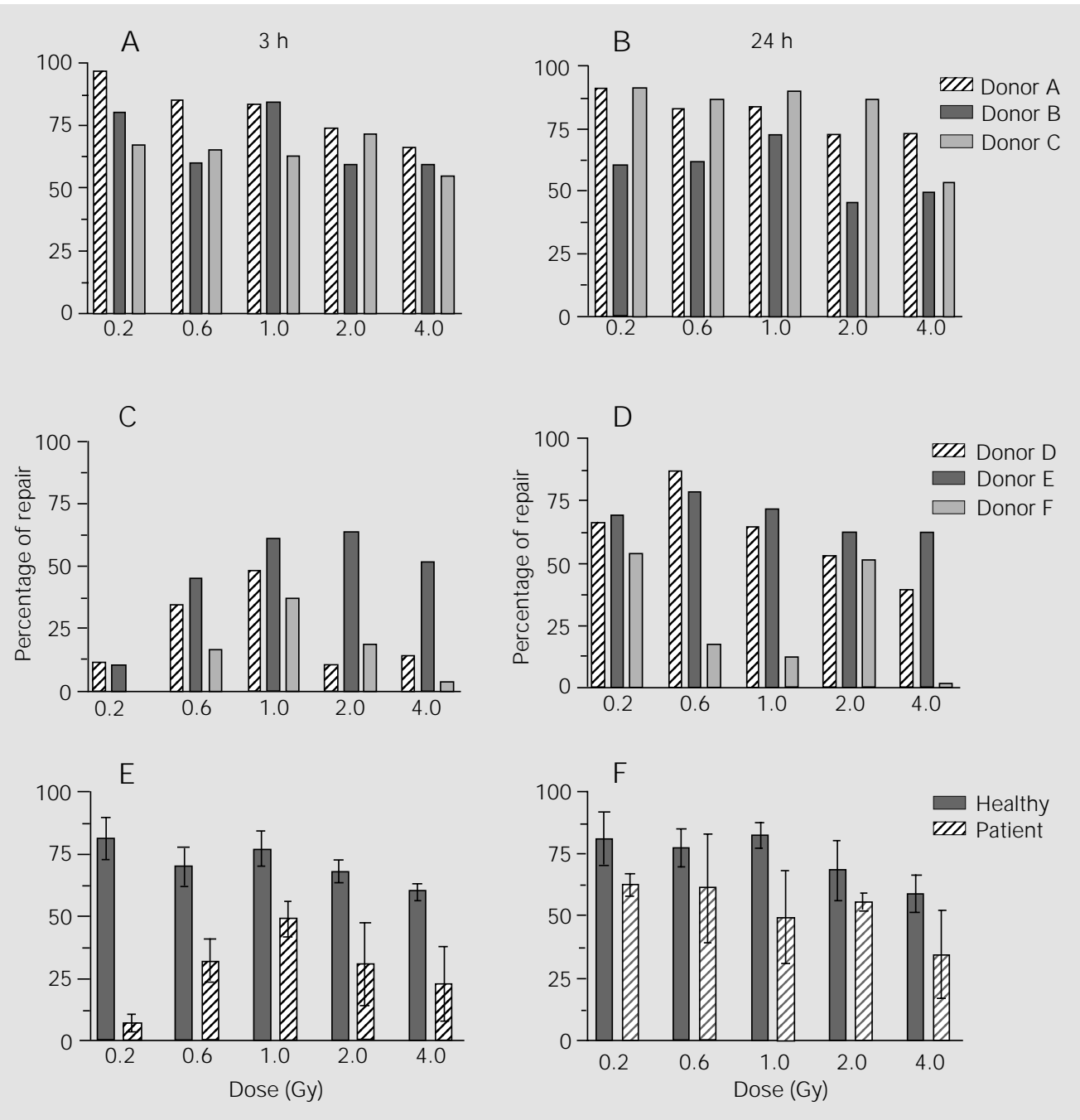

ciency in repair capacity. After $24 \mathrm{~h}$, only donor $\mathrm{E}$ had a performance equal to controls.

Among controls, donor $\mathrm{C}$ had a less efficient repair after $3 \mathrm{~h}$, but presented the best efficiency after $24 \mathrm{~h}$. We observed a tendency to a decrease in repair capacity of blood lymphocytes with increasing doses in both groups at 3 and $24 \mathrm{~h}$. The repair observed in peripheral blood cells from healthy donors after $24 \mathrm{~h}$ did not differ from that observed after $3 \mathrm{~h}$, whereas this difference was evident among patients. Statistical analysis showed that the repair capacity of the groups differed both $3 \mathrm{~h}(\mathrm{P}<0.001)$ and $24 \mathrm{~h}$ $(\mathrm{P}<0.05)$ after irradiation.

\section{Discussion}

Ionizing radiation is an etiologic agent known to act on the induction of breast cancer (21), but on the other hand it is a therapeutic modality used in cancer treatment. Therefore, a better knowledge of the action of ionizing radiation on the cellular response is of importance both clinically and therapeutically.

The head diameters obtained here for cells without DNA migration agreed with data reported by other laboratories $(20,22)$.

A significant difference in relation to basal values was observed between groups 
by tail measurement, but not by visual classification. This incongruent result may be explained by the fact that cells with little damage barely differ from cells with no damage so that visual analysis may not permit a distinction between them.

Statistical analysis showed no differences in results after 3 and $24 \mathrm{~h}$ of incubation. We conclude that the maintenance of blood samples for $24 \mathrm{~h}$ does not cause additional DNA lesions.

About the radioinduced damages, the dose-response curves for DNA migration (tail length) obtained just after irradiation showed an increase in tail length as a function of radiation dose. The increasing dose caused an increase in DNA lesions and so damaged filaments migrated to the anode during the electrophoretic run, giving origin to the comet tails. Statistical analysis showed no difference between groups, whereas the difference determined by visual classification (DD), although small, was considered significant. This result may be explained as a consequence of the slight difference between class 0 and class 1 .

In this context, we conclude that both groups had an analogous response when analyzed immediately after exposure. The initial radioinduced damage may have been quantitatively similar.

The quantitative estimation of repair capacity in blood lymphocytes showed that most of the radioinduced damage in the healthy group was repaired within $3 \mathrm{~h}$ while patients had more lesions even after $24 \mathrm{~h}$. These data show that the breast cancer donors analyzed in this study had deficient radioinduced damage repair. These data do not agree with those reported by Hsu et al. (13) who used bleomycin as a mutagenic test in peripheral blood lymphocytes from patients with various cancer types. The authors found a higher frequency of chromatid breaks per cell in patients with lung, colon and upper digestive tract cancer but not in breast cancer patients. They suggested that sensi- tivity to the mutagenic agents may play an important role in the carcinogenesis of tissues and organs in contact with the external environment, a fact that does not occur with mammary tissue.

In contrast, Jaloszynski et al. (14) reported that breast cancer patients were more sensitive to bleomycin by expressing higher level of DNA damage than controls, as observed in the comet assay.

The less efficient repair observed in blood lymphocytes in the present patients may explain the high basal level of damage.

Since carcinogenesis may originate from defects in DNA repair $(14,23)$, we may raise various hypotheses. The reduced repair capacity observed in these patients may be a consequence of mutations in genes involved in cell cycle control and DNA repair regulation. The tumor suppressor genes BRCA1, BRCA2, p53 or ATM are fundamental factors for the maintenance of genome integrity $(2,24)$.

Rothfuss et al. (15) observed that familial breast cancer patients with a mutated BRCA 1 gene show deficiency in radioinduced damage repair as detected by the micronucleus test. These data show a direct relation between BRCA1 mutation and radioinduced damage repair. Therefore, molecular analysis of the genes revealed that somatic mutations of either BRCA1 or BRCA2 are rare events in the majority of sporadic cases of breast and ovarian cancer $(2,6,23,25)$. Then, some authors such as Futreal et al. (26) raised the hypothesis that sporadic and familial tumors have different etiologies, suggesting that BRCA1 and BRCA2 may not play a critical role in the genesis of sporadic cancer cases.

If we consider the hypothesis that donors $\mathrm{D}$ and $\mathrm{F}$ are carriers of mutated genes, we could partially explain their significantly lower repair capacity than donor $\mathrm{E}$ who has no history of cancer in her family, although no molecular gene analysis was done. Donors $\mathrm{D}$ and $\mathrm{F}$ have first- and second-degree 
relatives with ovarian and breast cancer, besides other types of cancer in the families. There seems to be a predisposition to cancer development in their families, although we cannot rule out the hypothesis of exposure of the entire family to the same carcinogenic agent.

Other genes may be involved but further studies are necessary to test this possibility. One of the possible genes involved is p53, which has been described in almost all human cancers, including breast cancer (27), and plays a role in the repair mechanism of radioinduced damage (9). There is evidence that p53 and rad51 are involved in vivo (28).

We cannot rule out the possibility of an ATM gene action since this gene acts on BRCA1 phosphorylation after exposure to ionizing radiation as an initial signal for the recombinational repair process of DNA double-strand breaks (24). The sensitivity to ionizing radiation is also observed in ataxia telangiectasia patients who are defective in DNA strand break repair. The disease is related to ATM gene mutation and heterozygotes are $0.5-1 \%$ of the population more predisposed to breast cancer (2).

These observations suggest the occurrence of other genes that can act in the same way as suppressor genes. On this basis, various other molecular targets for sporadic tumors may exist (26).

In relation to controls, the blood cells from donor $\mathrm{C}$ showed the most efficient repair after $24 \mathrm{~h}$, suggesting a slower repair mechanism than in the other donors.

Patient age was not an important factor because the oldest one, donor E, showed the best repair. The control group ranged in age from 40-50 years. A possible influence of age may have affected the comparison between groups.

The relation between age and damage susceptibility in somatic cells had been studied but data are contradictory. Duffaud et al. (29) and Peace and Succop (30) observed an increase in the frequency of affected cells with aging. This could be attributed to the accumulation of genetic damage in cells (31) or to the aging process, such as altered cellular metabolism and/or decrease in the efficiency of DNA repair (32). Other authors, however, did not find any association between age and genetic damage in cells $(33,34)$.

The influence of gender is not significant for the biological response to environmental genotoxic agents $(29,30)$, although some evidence shows that women are more susceptible to some carcinogenic agents (35).

In addition to these considerations, there is the possibility that the difference between groups was a consequence of the pathological stage (malignancy) of the tumors. Other factors such as immunological, metabolic and dietary ones, also considering that life style is influenced by various environmental agents that can act synergistically, have been suggested by several authors $(29,33)$. Therefore, nothing that could explain the difference between patients and healthy donors was observed in the replies to the questionnaire.

Ionizing radiation is known to induce multiple DNA lesions (17). Although the comet assay does not permit the direct identification of the damage or repair mechanism involved, it is known that the $\mathrm{pH}$ of the electrophoresis buffer is a fundamental factor: under neutral conditions, double-strand breaks are the type of damage most frequently detected, while under alkaline conditions $(\mathrm{pH}>12)$, as used in the present study, single- and double-strand breaks as well as alkali-labile lesions make a significant contribution to the DNA quantity found in comet tails $(16,18)$.

Studies of repair kinetics in blood cells from healthy donors showed that many low LET radioinduced lesions such as base damage are repaired within the first $15 \mathrm{~min}$, while a slower repair mechanism that acts on alkalilabile lesions, single-strand breaks and principally double-strand breaks is completed within 
2 h (16-18). Olive (36) described a slower repair system for more complex lesions, which was completed only after 30-40 h.

Based on this information, we suggest that the discordant results obtained by Rothfuss et al. (15) may have been due to the period of time used to check the breast cancer cell repair. The authors did not find a significant difference in repair induced by 2 Gy ${ }^{60} \mathrm{Co}$ analyzed one hour later by the comet assay, but did find a difference by the micronucleus test used to evaluate the non-repaired damage.

Double-strand breaks are among the most difficult radioinduced lesions to repair. Nonrepaired damage can result in cell death, aging and cancer.

Both parameters adopted in the present study, i.e., comet measurement and visual classification, proved to be safe and sensitive and therefore could be used as an alternative method for the evaluation of cellular response.

The results showed that cellular radio- sensitivity depends not only on the amount of imposed initial damage, but also on the cell repair capacity, among other factors.

Since in the present study only a small number of patients and controls was analyzed, it is necessary to investigate a larger number of donors including other family members, with an equal distribution of patients and healthy donors with respect to age, gender and other risk factors of increased DNA fragility, and to perform molecular analysis of possible genes involved in breast cancer susceptibility for a more accurate evaluation.

\section{Acknowledgments}

The authors are indebted to Dr. Regina Godoy Lopes, Instituto de Radioterapia de São Paulo, São Paulo, SP, Brazil, for supplying the blood samples from the patients, and to Dr. Maria Aparecida Pires Camillo for the statistical analysis.

\section{References}

1. Sankaranarayanan $\mathrm{K} \&$ Chakraborty $\mathrm{R}$ (1995). Cancer predisposition, radiosensitivity and the risk of radiation-induced cancers. I. Background. Radiation Research, 143: 121-143.

2. Venkitaraman AR (1999). Breast cancer genes and DNA repair. Science, 286: 1100-1102.

3. Easton DF, Bishop DT, Ford D \& Crockford GP (1993). Genetic linkage analysis in familial breast and ovarian cancer: results from 214 families. The breast cancer linkage consortium. American J oumal of $\mathrm{Hu}$ man Genetics, 52: 678-701.

4. Rahman N \& Stratton MR (1998). The genetics of breast cancer susceptibility. Annual Review of Genetics, 32: 95-121.

5. Machado CR \& Menck CFM (1997). Human DNA repair diseases: from genome instability to cancer. Brazilian J ournal of Genetics, 20: 755-762.

6. Scully R, Chen J, Plug A, Xiao Y, Weaver D, Feunteun J , Ashley T \& Livingston DM (1997). Association of BRCA1 with Rad51 in mitotic and meiotic cells. Cell, 88: 265275.

7. Smith ML, Chen I-T, Zhan Q, Bae I, Chen C-Y, Gilmer TM, Kastan MB, O'Connor PM \& Fornace J r AJ (1994). Interaction of the p53-regulated protein Gadd45 with proliferating cell nuclear antigen. Science, 266: 1376-1380.

8. Mallya SM \& Sikpi MO (1998). Evidence of the involvement of p53 in gamma-radiation-induced DNA repair in human lymphoblasts. Intemational J ournal of Radiation Biology, 74: 231-238.

9. Rigaud O, Guedeney G, Duranton I, Leroy A, Doloy MT \& Magdelenat H (1990). Genotoxic effects of radiotherapy and chemotherapy on the circulating lymphocytes of breast cancer patients. I. Chromosome aberrations induced in vivo. Mutation Research, 242: 17-23.

10. Helzlsouer KJ , Harris EL, Parshad R, Fogel S, Bigbee WL \& Sanford KK (1995). Familial clustering of breast cancer: possible interaction between DNA repair profi- ciency and radiation exposure in the development of breast cancer. International J ournal of Cancer, 64: 14-17.

11. Parshad R, Price FM, Bohr VA, Cowans KH, Zujewski JÁ \& Sanford KK (1996). Deficient DNA repair capacity, a predisposing factor in breast cancer. British J ournal of Cancer, 74: 1-5.

12. Scott $D$, Barber J BP, Levine EL, Burrill W $\&$ Roberts SA (1998). Radiation-induced micronucleus induction in lymphocytes identifies a high frequency of radiosensitive cases among breast cancer patients: a test for predisposition? British J ournal of Cancer, 77: 614-620.

13. Hsu TC, J ohnston DA, Cherry LM, Ramkissoon D, Schantz SP, J essup J M, Winn RJ , Shirley L \& Furlong C (1989). Sensitivity to genotoxic effects of bleomycin in humans: possible relationship to environmental carcinogenesis. International J ournal of Cancer, 43: 403-409.

14. Jaloszynski P, Kujawski M, CzubSwierczek M, Markowska J \& Szyfter K 
(1997). Bleomycin-induced DNA damage and its removal in lymphocytes of breast cancer patients studied by comet assay. Mutation Research, 385: 223-233.

15. Rothfuss A, Schutz $P$, Bochum $S$, Volm T, Eberhardt E, Kreienberg R, Vogel W \& Speit G (2000). Induced micronucleus frequencies in peripheral lymphocytes as a screening test for carriers of a BRCA1 mutation in breast cancer families. Cancer Research, 60: 390-394.

16. Singh NP, McCoy MT, Tice RR \& Schneider EL (1988). A simple technique for quantitation of low levels of DNA damage in individual cells. Experimental Cell Research, 175: 184-191.

17. Price A (1993). The repair of ionising radiation-induced damage to DNA. Cancer Biology, 4: 61-71.

18. Tice RR (1995). The single cell gel/comet assay: a microgel electrophoretic technique for the detection of DNA damage and repair in individual cells. In: Phillis DH $\&$ Venitt S (Editors), Environmental Mutagenesis. Bioscientific, Oxford, 315-339.

19. McKelvey-Martin V], Green MHL, Schmezer P, Poolzobel BL, De Méo MP \& Collins A (1993). The single cell gel electrophoresis assay (comet assay): A European review. Mutation Research, 288: 47-63.

20. Visvardis E-E, Tassiou AM \& Piperakis SM (1997). Study of DNA damage induction and repair capacity of fresh and cryopreserved lymphocytes exposed to $\mathrm{H}_{2} \mathrm{O}_{2}$ and $\gamma$-irradiation with the alkaline comet assay. Mutation Research, 383: 71-80.

21. van Bekkum DW \& Broerse JJ (1991). Induction of mammary tumors by ionizing radiation. Radiation and Environmental Biophysics, 30: 217-220.

22. Singh NP \& Stephens RE (1997). Microgel electrophoresis: sensitivity, mechanisms, and DNA electrostretching. Mutation Research, 383: 167-175.

23. Kinzier KW \& Vogelstein B (1997). Gatekeepers and caretakers. Nature, 386: 761-763.

24. Cortez D, Wang Y, Qin J \& Elledge SJ (1999). Requirement of ATM-dependent phosphorylation of BRCA1 in the DNA damage response to double-strand breaks. Science, 286: 1162-1166.

25. Sharan SK, M orimatsu M, Albrecht U, Lim D-S, Regel E, Dinh C, Sands A, Eichele G, Hasty P \& Bradley A (1997). Embryonic lethality and radiation hypersensitivity mediated by Rad51 in mice lacking BRCA2. Nature, 386: 804-810.

26. Futreal PA, Liu Q, Shattuck-Eidens D, Cochran C, Harshman K, Tavtigian S, Bennett LM, Haugen-Strano A, Swensen J, Miki Y, Eddington K, McClure M, Frye C, Weaver-Feldhaus J, Ding W, Gholami Z, Söderkvist $P$, Terry L, J hanwar S, Berchuck A, Iglehart J D, Marks J, Ballinger DG, Barrett J C, Skolnick MH, Kamb A \& Wiseman R (1994). BRCA1 mutations in primary breast and ovarian carcinomas. Science, 266: 120-122.

27. Hollstein $M$, Sidransky $D$, Vogelstein $B \&$ Harris CC (1991). p53 mutations in human cancers. Science, 253: 49-53.

28. Sturzbecher HW, Donzelmann B, Henning W, Knippschild U \& Buchhop S (1996). p53 is linked directly to homologous recombination processes via RAD51/RecA protein interaction. EMBO J ournal, 15: 1992-2002.

29. Duffaud $F$, Orsière $T$, Villani $P$, Pelissier AL, Volot F, Favre R \& Botta A (1997). Comparison between micronucleated lymphocyte rates observed in healthy subjects and cancer patients. Mutagenesis, 12: 227-231.

30. Peace BE \& Succop P (1999). Spontaneous micronucleus frequency and age: what are normal values? Mutation Research, 425: 225-230.

31. Fenech M \& Morley AA (1989). Kinetochore detection in micronuclei: an altemative method for measuring chromosome loss. Mutagenesis, 4: 98-104.

32. Ganguly BB (1993). Cell division, chromosomal damage and micronucleus formation in peripheral lymphocytes of healthy donors: related to donor's age. Mutation Research, 295: 135-148.

33. Sarto F, Finotto S, Giacomelli L, Mazzotti D, Tomanin R \& Levis AG (1987). The micronucleus assay in exfoliated cells of the human buccal mucosa. Mutagenesis, 2: 11-17.

34. Gantenberg H-W, Wuttke K, Streffer C \& Muller W-U (1991). Micronuclei in human lymphocytes irradiated in vitro or in vivo. Radiation Research, 128: 276-281.

35. Perera FP (1997). Environment and cancer: who are susceptible? Science, 278: 1068-1073.

36. Olive OL (1998). The role of DNA singleand double-strand breaks in cell killing by ionizing radiation. Radiation Research, 150 (Suppl): S42-S51. 